Article

\title{
Improvement of Sorghum Crop through Exogenous Application of Natural Growth-Promoting Substances under a Changing Climate
}

\author{
Wahid Ahmad 1,2,+, Mehmood Ali Noor ${ }^{3, *,+}$, Irfan Afzal ${ }^{2}$, Muhammad Amir Bakhtavar ${ }^{2}$, \\ Muhammad Mohsin Nawaz ${ }^{3}$, Xuefang Sun ${ }^{3}$, Baoyuan Zhou ${ }^{3}$, Wei Ma ${ }^{3}$ and Ming Zhao ${ }^{3}$ \\ 1 Faculty of Agricultural Sciences, George August Göttingen University, 37073 Göttingen, Germany; \\ wahid.ahmad@stud.uni-goettingen.de \\ 2 Department of Agronomy, University of Agriculture, Faisalabad 38040, Pakistan; iafzal@uaf.edu.pk (I.A.); \\ mbakhtavar@ucdavis.edu (M.A.B.) \\ 3 Institute of Crop Science, Chinese Academy of Agricultural Sciences/Key Laboratory of Crop Physiology \\ and Ecology, Ministry of Agriculture, Beijing 100081, China; mcheema77@hotmail.com (M.M.N.); \\ sunxf2013caas@163.com (X.S.); zhoubaoyuan2008@163.com (B.Z.); mawei02@caas.cn (W.M.); \\ zhaoming@caas.cn (M.Z.) \\ * Correspondence: mnoor@ksu.edu.sa or mehmood2017@gmail.com \\ + These authors contribute equally to this work.
}

Academic Editor: Iain Gordon

Received: 12 August 2016; Accepted: 11 December 2016; Published: 16 December 2016

\begin{abstract}
High temperature during May to July is a major hurdle for production of sorghum as fodder in Pakistan, ultimately resulting in a deficit with respect to the demand of meat and milk for increasing population. A field study was conducted to investigate the impact of exogenous application of natural plant growth-promoting substances on forage yield and quality of sorghum. Seed priming and foliar application (alone or in combination) with 1\% sorghum water extract (SWE), 3\% moringa leaf extract (MLE) and water were applied. Two foliar applications, the first at one month after sowing and the second at 45 days after sowing were carried out. Untreated seeds were used as control. The results indicated that priming and foliar spray performed best in combination as compared to priming or foliar application alone. All MLE applications (priming plus foliar application, priming alone, foliar spray alone) enhanced growth parameters and chlorophyll contents, which ultimately improved forage yield and total dry matter production of sorghum plants. An increase in crude protein and total ash and decrease in crude fiber was also recorded in plants treated with MLE. The results of this study revealed that exogenous application of MLE at 3\% concentration (priming plus foliar application, priming alone, foliar spray alone) significantly enhanced the yield through improvement in sorghum growth.
\end{abstract}

Keywords: exogenous application; moringa leaf extract; sorghum leaf extract; sorghum forage; seed priming; foliar spray

\section{Introduction}

Climate change is a major concern for future crop production and food security [1]. The frequency of high temperature stress is likely to increase, which can reduce leaf area, photosynthesis, kernel weight and sugar contents of cereals [2]. In addition, the growth periods of crop plants are shortened, which result in reduced light interception and lower biomass production, thereby reducing economic yields [3]. High temperature stress for short time spans causes severe cell injury and even death [4], whereas mild heat stress (up to $35^{\circ} \mathrm{C}$ ) leads to enzyme inactivation in chloroplast and mitochondria, and protein denaturation along with cell membrane disruption [5]. Specifically, this mild heat stress 
impairs photosynthetic efficiency by lowering Rubisco activity [6] due to heat susceptibility of Rubisco activase [7]. Ultra-high temperatures $\left(>35^{\circ} \mathrm{C}\right)$ destabilize photosystem II activity by inhibiting electron transport due to affected oxygen-evolving complex [8].

Various strategies are being used to relieve the crops from high temperatures, such as use of stress-tolerant cultivars. Defense mechanisms with respect to any particular type of stress depend on the genetic makeup of crop plants and their physiological ability to combat that stress. Numerous studies have shown that the external application of certain natural and synthetic plant growth regulators (PGRs) and chemicals has the capacity to alleviate biotic and abiotic stress effects in plants by regulating abnormal physiological processes [9-13]. Presently, exogenous application of various PGRs is a novel physiological approach for improving germination, plant growth and crop yield [14]. PGRs can enhance the growth and yield of crops under abiotic stresses [15]. Seed priming has also given good results for increasing the yield of horticultural [16] as well as cereal crops like maize and sorghum [11]. Allelochemicals, mostly known for their growth inhibitory effects, can also serve as plant growth promoters at low concentrations [12]. Underlying mechanisms for stimulatory effects of these allelochemicals include the physiological regulation of the activity of different enzymes, hormonal balances, cell division promotion and increased ion uptake [17]. Among many other arable crops, sorghum and moringa leaf water extracts improved growth of various crops and vegetables when applied at low concentrations $[11,18,19]$.

Moringa oleifera, as a good source of antioxidant agents [20], can be a growth enhancer when its leaf extract is applied as seed pretreatment [16] or foliar spray [15], making crops more vigorous and resistant against heat stress [11]. Foliar spray of moringa leaf extract (MLE) is reported to increase seasonal leaf area duration, delayed leaf senescence and photosynthetic activity by improving chlorophyll contents, as well as increasing the stay-green in cereals [21]. Growth improvement due to MLE treatment is attributed to the presence of various hormones, especially zeatin. Secondary metabolites (ascorbates and phenols) in moringa leaves act as concealment with respect to reactive oxygen species (ROS) production during heat stress [10,22].

Water extracts of sorghum, one of the most important and widely studied allelopathic crops [17], are a rich source of various phenolics such as vanillic acid, $p$-hydroxybenzoic acid, $p$-hydroxybenzaldehyde, ferulic acid and $p$-coumaric acid $[23,24]$. These secondary metabolites have been reported for their potential to promote germination and growth when applied at low concentrations [25]. These chemicals, when applied through foliar application of sorghum water extract (SWE), can reduce the detrimental effects (damage to biomolecules like lipids, proteins and DNA) of free radicals which are produced in plants under heat stress conditions [26].

Sorghum (Sorghum bicolor L.), locally known as Jowar or Charry, is an important drought-resistant summer crop gown for dual purposes (seed and forage) in Pakistan. The quality of fodder is as important as dry matter yield. Many factors influence forage yield of sorghum, such as timely sowing, seed health, adequate use of agricultural inputs like irrigation and fertilizer, planting of high yielding varieties, and efficient weed control [27]. Another important factor is poor crop stand establishment and high temperature stress during the whole crop season for May grown sorghum, which ultimately results in reduced biomass and poor nutritional quality.

However, limited work has been reported on improvement of sorghum forage and grain yield through application of natural growth-promoting substances, especially SWE and MLE. Keeping in view the effectiveness of natural plant growth promoting substances in growth and yield enhancement of various crops, the present study investigated the effects of exogenous application of natural growth-promoting substances on growth and forage yield of sorghum under high temperature stress. Furthermore, role of these growth-promoting substances in quality improvement of sorghum forage was also determined. 


\section{Materials and Methods}

\subsection{Experimental Site and Design}

A field experiment was conducted to investigate the effects of growth-promoting substances on biomass yield and quality of sorghum at University of Agriculture, Faisalabad, Pakistan in the summer of 2014. Randomized complete block design (RCBD) was used with three replications. Net plot size was $1.8 \mathrm{~m} \times 6 \mathrm{~m}$. The experiment was comprised of ten treatments, viz. hydropriming, priming with $1 \%$ SWE, priming with 3\% MLE, foliar spray with water, foliar spray with $1 \%$ SWE, foliar spray with $3 \%$ MLE, priming plus foliar spray with water, priming plus foliar spray with $1 \%$ SWE and priming plus foliar spray with 3\% MLE. Untreated seeds were used as a control. Maximum and minimum temperature fluctuations for the whole crop season are presented in Figure 1.

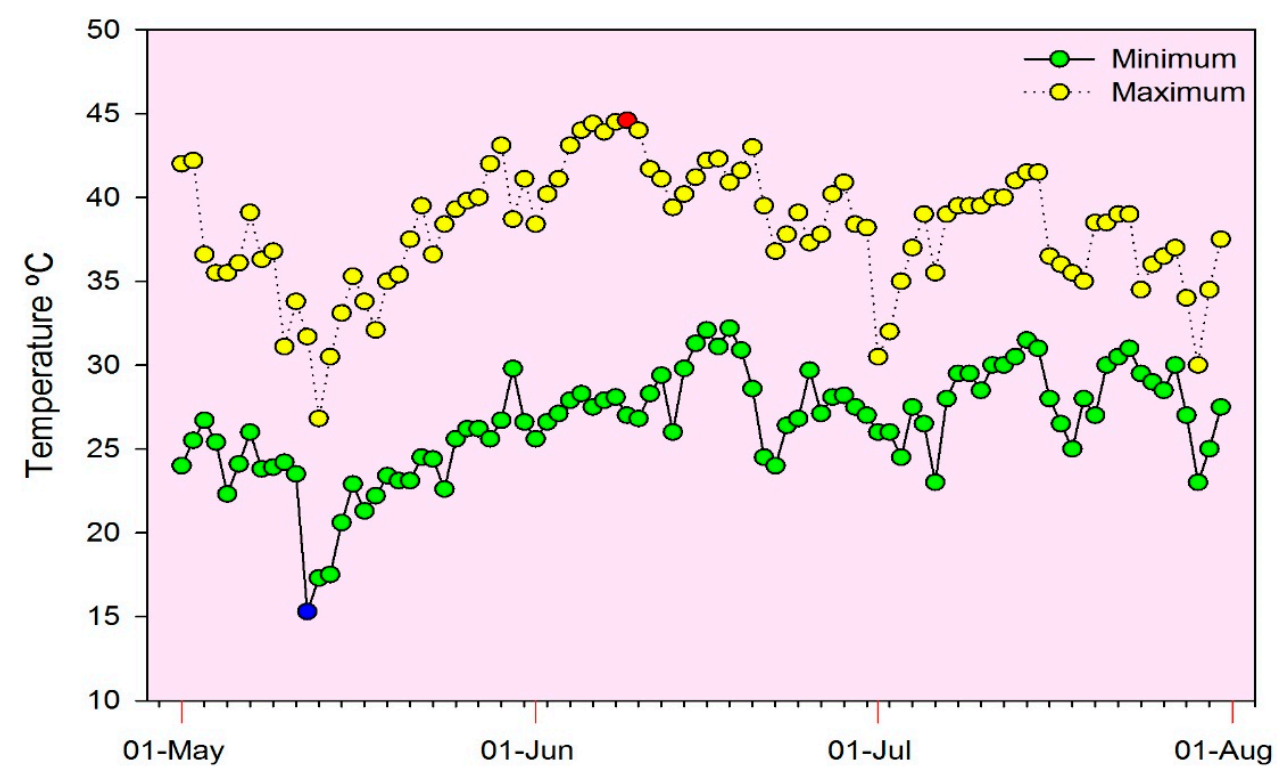

Figure 1. Daily temperature fluctuations for the sorghum growth season in 2014. Red and blue circles in series are representing the highest and lowest temperature during crop growth period, respectively.

\subsection{Dose Optimization for PGRs}

MLE and SWE doses were optimized in a lab experiment. Sorghum seeds were pretreated with natural extracts then allowed to germinate in Petri dishes. Among various concentrations $(v / v)$ of MLE (1\%, 3\%, and 5\%) and SWE $(0.5 \%, 1 \%$ and $2 \%)$, MLE 3\% and SWE $1 \%$ showed the best results for sorghum seed germination and were used in the field experiment.

\subsection{Extraction of Moringa Leaf Extract}

Fresh moringa leaves were used to extract juice using a locally manufactured machine following the method of Foidl et al. [10]. The young leaves and tender branches were ground with water $(1 \mathrm{~L} / 10 \mathrm{~kg}$ fresh material) and the extracted juice was sieved through cheese cloth. Afterwards, the extract was diluted with distilled water to obtain a $3 \%$ concentration $(v / v)$ by adding $30 \mathrm{~mL}$ of the prepared leaf extract to distilled water in a 1000-mL flask [11].

\subsection{Preparation of Sorghum Water Extract}

Sorghum extracts were prepared using mature, dried and chaffed sorghum herbage soaked in water at ratio of 1:10 $(w / v)$ for $24 \mathrm{~h}$, and passed through sieves number 10 and 60 to collect SWE [26]. The obtained filtrate was 100\% concentrated which was then diluted to its respective concentration $(1 \% v / v)$ by dissolving $10 \mathrm{~mL}$ of concentrate in a 1000-mL flask filled with distilled water. 


\subsection{Seed Priming Protocol and Material Used}

Sorghum seeds were primed by soaking seeds in 3\% solution of MLE and $1 \%$ solution of SWE in plastic tubs for $10 \mathrm{~h}$, while providing continuous supply of oxygen through an aquarium pump. The soaking ratio of seed to working solutions was $1: 5\left(\mathrm{~g} \cdot \mathrm{mL}^{-1}\right)$. After desirable soaking, primed seeds were re-dried under shade to their approximate original weights.

\subsection{Foliar Spray}

Foliar spray treatments including water spray, MLE (3\%) and SWE (1\%) were applied at 30 and 45 days after sowing (DAS). In total, $75 \mathrm{~mL}$ of MLE in $2500 \mathrm{~mL}$ and $25 \mathrm{~mL}$ of SWE in $2500 \mathrm{~mL}$ of water was used for foliar application on six plots (designated for foliar treatments) for each replication. All the foliar spray treatments were applied during evening time using a hand-held precision sprayer (backpack piston sprayer; agros-AM-S016A).

\subsection{Field Operations}

The sorghum crop was sown on 4 May 2014, with a row spacing of $30 \mathrm{~cm}$ using a single-row hand drill. The seeding rate was $80 \mathrm{~kg} \cdot \mathrm{ha}^{-1}$. Nitrogen $(\mathrm{N})$ and phosphorus $(\mathrm{P})$ fertilizers were applied at the rate of 80 and $58 \mathrm{~kg} \cdot \mathrm{ha}^{-1}$ in the form of urea $(46 \% \mathrm{~N})$ and single super phosphate $\left(18 \% \mathrm{P}_{2} \mathrm{O}_{5}+\right.$ $12 \%$ sulfur), respectively. A whole dose of $\mathrm{P}$ and half of the $\mathrm{N}$ was applied during field preparation, while other $\mathrm{N}$ half was top-dressed at first irrigation (20 DAS). All other agronomic practices were kept normal and uniform whilst no irrigation stress was observed during whole crop season. The crop was harvested on 18 July 2014.

\subsection{Measurements}

\subsubsection{Seedling Stand Establishment}

The numbers of emerged seeds were daily recorded as per the protocols of the Seedling Evaluation Handbook of Association of Official Seed Analysts [28]. The following equation [29] was used to calculate mean emergence time (MET):

$$
M E T=\frac{\sum D n}{\sum n}
$$

where $n$ denotes the number of seeds, which emerged on day $D$, and $D$ is the number of days counted from the beginning of emergence. The formula of Coolbear et al. [30] was used to calculate the time taken to $50 \%$ emergence $\left(E_{50}\right)$ :

$$
E_{50}=t i+\frac{\left(\frac{N}{2}-n i\right)(t j-t i)}{n j-n i}
$$

Here, $N$ represents the final number of seeds emerged and $n i$ and $n j$ represent the cumulative numbers of seeds which germinated by adjacent counts at times $t i$ and $t j$, respectively, when $n i<N / 2<n j$.

\subsubsection{Growth Parameters}

The total number of plants from an area of $0.9 \mathrm{~m}^{2}$ (comprised of three rows, each $1 \mathrm{~m}$ long) at the time of harvest were counted at three randomly selected places in each plot and then averages were taken to determine plant density per $\mathrm{m}^{2}$. Ten plants were randomly selected from each plot and their height $(\mathrm{cm})$ was measured. Similarly, the stem diameter $(\mathrm{cm})$ of plants was measured with digital vernier caliper from the base, middle and top portion [31]. Already selected plants were used to calculate average leaf weight $(\mathrm{g})$ per plant and leaf area per plant $\left(\mathrm{m}^{-2}\right)$ in which all the leaves from plants were removed and passed through a LI-3000C portable leaf area meter (LI-COR Inc., Lincoln, 
NE, USA). Three days after the second foliar spray, ten randomly selected plants were harvested from each plot to calculate fresh weight. Harvested plants were quickly weighed in the field to avoid any moisture loss. Harvested plants were dried under the sun for 10 days and then reweighted to determine dry weight.

\subsubsection{Biochemical Analysis}

Plant samples were taken 7 days after second spray i.e., almost 50 DAS, and were kept in biomedical freezer at $-30{ }^{\circ} \mathrm{C}$. Plant material $(1 \mathrm{~g})$, thoroughly homogenized with acetone-hexane mixture (4:6 ratio) using mortar pestle was used to extract chlorophyll contents. Then the mixture was centrifuged at $3000 \mathrm{rpm}$ for $10 \mathrm{~min}$. The supernatant was used to measure the absorbance at $663 \mathrm{~nm}$ and $645 \mathrm{~nm}$ by spectrophotometer UV-4000 (O.R.I., Hamburg, Germany) using $80 \%$ acetone as blank. The following equations were used to calculate chlorophyll $a$ and $b$ contents:

$$
\begin{aligned}
& \text { Chlorophyll } a(\mathrm{mg} / 100 \mathrm{~mL})=0.999 A_{663}-0.0989 A_{645} \\
& \text { Chlorophyll } b(\mathrm{mg} / 100 \mathrm{~mL})=-0.328 A_{663}+1.77 A_{645}
\end{aligned}
$$

2.8.4. Quality Parameters

Crude fiber percentage (CF\%) was determined by filtration method [32] and calculated as follows:

$$
\mathrm{CF} \%=\frac{\text { Weight of dry residue }- \text { Weight of ash }}{\text { Weight of moisture free samples }} \times 100
$$

Crude protein contents (\%) were determined by using Micro Kjeldahl method [32]. Likewise, total ash was determined by muffle furnace burning method [32], and calculated as:

$$
\text { Ash } \%=\frac{\text { Weight of ash }}{\text { Weight of sample }} \times 100
$$

\subsubsection{Yield Attributes}

For measuring yield parameters, green forage of each plot for each replication was cut (85 DAS), total mass was weighed and forage yield was presented in tons per ha. Green forage was dried at $80^{\circ} \mathrm{C}$ to constant weight. The dry matter percentage per plot was calculated and used for converting green forage yield into dry matter yield $\left(\mathrm{t} \cdot \mathrm{ha}^{-1}\right)$ by using following formula:

$$
\text { Dry matter yield }=(\text { Fresh forage yield } \times \text { Dry matter percentage }) / 100
$$

\subsubsection{Statistical Analysis}

Data collected on growth, yield and quality parameters were analyzed using Fisher's analysis of variance (ANOVA) and least significant difference test (LSD). A 5\% probability level was used to compare the differences among treatment means [33].

\section{Results}

Exogenous application of priming and foliar spray treatments alone and in combination significantly influenced the stand establishment, growth, yield and quality attributes of sorghum (Table 1). 
Table 1. Analysis of variance (ANOVA) summary for the results of exogenous application of growth-promoting substances on sorghum performance under field conditions.

\begin{tabular}{ccc}
\hline Measurements & D.F. & Priming and Foliar Treatments \\
\hline MET & 9 & $35.56^{* *}$ \\
$E_{50}$ & 9 & $10.95^{* *}$ \\
Plant density & 9 & $14.92^{* *}$ \\
Plant height & 9 & $11.28^{* *}$ \\
Stem diameter & 9 & $9.54^{* *}$ \\
Number of leaves per plant & 9 & $2.99^{*}$ \\
Leaf weight $(\mathrm{g})$ per plant & 9 & $24.48^{* *}$ \\
Leaf area per plant $\left(\mathrm{m}^{2}\right)$ & 9 & $23.68^{* *}$ \\
Fresh weight per plant $(\mathrm{g})$ & 9 & $23.60^{* *}$ \\
Dry weight per plant $(\mathrm{g})$ & 9 & $23.87^{* *}$ \\
Chlorophyll $a$ & 9 & $13.06^{* *}$ \\
Chlorophyll $b$ & 9 & $1.45^{\mathrm{NS}}$ \\
Crude fiber & 9 & $325.84^{* *}$ \\
Crude protein & 9 & $60.39^{* *}$ \\
Total ash (\%) & 9 & $240.19^{* *}$ \\
Total forage yield & 9 & $9.71^{* *}$ \\
Total dry matter yield & 9 & $12.31^{* *}$ \\
\hline
\end{tabular}


$p<0.01 ; \mathrm{NS}=$ non-significant, D.F. $=$ degree of freedom.

\subsection{Stand Establishment}

Daily emergence count showed vigorous stand establishment of sorghum seeds pretreated with natural growth-promoting substances (Figure 2). Emergence rate was higher in primed seeds as compared to untreated control seeds. Maximum emergence was recorded in seeds primed with MLE followed by MLE priming plus foliar spray treatment. Consistency and uniformity in seedling emergence was also observed. However, a weaker, irregular emergence pattern was noticed in untreated seeds and the difference was quite significant from the start of sowing until final count of emergence (Figure 2).

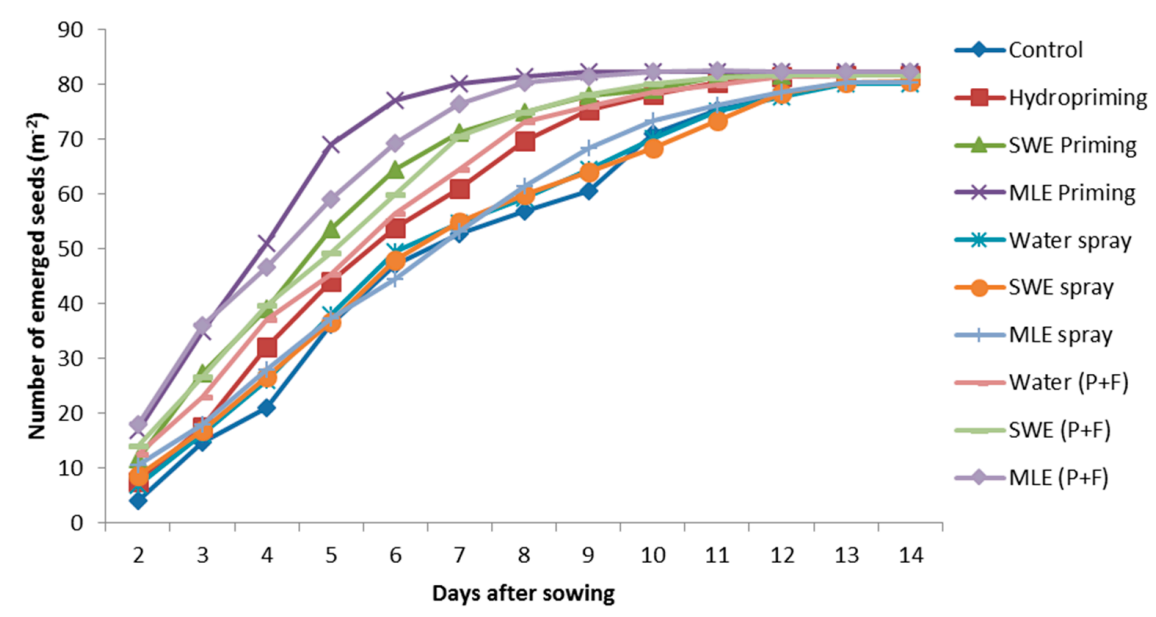

Figure 2. Effect of exogenously applied plant growth-promoting substances on daily seedling emergence in sorghum. MLE, moringa leaf extract; SWE, sorghum water extract; $\mathrm{P}$, priming; F, foliar spray.

All the exogenous treatments significantly reduced the MET and the minimum MET was found in sorghum seeds primed with MLE (Table 2), which was statistically similar to treatment of priming plus foliar spray with MLE (4.9 days). The highest mean emergence time (6.6 days) was seen in the control. Similarly, time taken to $50 \%$ emergence in sorghum was significantly reduced by the MLE priming treatment which resulted in lowest $E_{50}$ value (3.4 days). 
Table 2. Effect of seed priming and foliar application strategies on stand establishment and agronomic traits of sorghum under field conditions.

\begin{tabular}{|c|c|c|c|c|c|c|}
\hline Treatments & MET (Days) & $E_{50}$ (Days) & Plant Density $\left(\mathrm{m}^{-2}\right)$ & Plant Height $(\mathrm{cm})$ & Stem Diameter $(\mathrm{cm})$ & Number of Leaves Per Plant \\
\hline Control & $6.56 \pm 0.06 \mathrm{a}$ & $5.37 \pm 0.18 \mathrm{ab}$ & $36 \pm 2.64 c$ & $131 \pm 0.88 c$ & $0.67 \pm 0.11 \mathrm{c}$ & $7 \pm 0.33 b$ \\
\hline Hydropriming & $5.64 \pm 0.15 \mathrm{~b}$ & $4.74 \pm 0.20 \mathrm{bcd}$ & $49 \pm 5.51 \mathrm{~b}$ & $133 \pm 2.52 \mathrm{c}$ & $0.71 \pm 0.05 \mathrm{bc}$ & $8 \pm 0.58 b$ \\
\hline SWE Priming & $4.90 \pm 0.14 \mathrm{c}$ & $4.12 \pm 0.25 \mathrm{de}$ & $53 \pm 2.52 b$ & $137 \pm 3.76 \mathrm{c}$ & $0.70 \pm 0.05 \mathrm{bc}$ & $7 \pm 1.00 \mathrm{~b}$ \\
\hline MLE Priming & $4.01 \pm 0.10 \mathrm{~d}$ & $3.39 \pm 0.18 \mathrm{f}$ & $63 \pm 1.76 a$ & $154 \pm 1.73 \mathrm{~b}$ & $0.80 \pm 0.06 \mathrm{~b}$ & $8 \pm 1.53 b$ \\
\hline Water foliar spray & $6.29 \pm 0.15 a$ & $5.17 \pm 0.09 \mathrm{abc}$ & $38 \pm 2.08 c$ & $132 \pm 3.61 \mathrm{c}$ & $0.67 \pm 0.09 c$ & $8 \pm 0.88 b$ \\
\hline SWE foliar spray & $6.33 \pm 0.06 \mathrm{a}$ & $5.28 \pm 0.22 \mathrm{ab}$ & $53 \pm 2.52 b$ & $134 \pm 4.58 \mathrm{c}$ & $0.76 \pm 0.06 \mathrm{bc}$ & $8 \pm 1.20 \mathrm{~b}$ \\
\hline MLE foliar spray & $6.16 \pm 0.10 \mathrm{~b}$ & $5.59 \pm 0.15 \mathrm{a}$ & $54 \pm 1.73 \mathrm{~b}$ & $153 \pm 4.67 \mathrm{~b}$ & $0.82 \pm 0.06 \mathrm{~b}$ & $9 \pm 0.88 \mathrm{~b}$ \\
\hline Water priming + foliar spray & $5.30 \pm 0.06 \mathrm{bc}$ & $4.48 \pm 0.14 \mathrm{~cd}$ & $38 \pm 3.06 c$ & $133 \pm 2.33 c$ & $0.73 \pm 0.03 \mathrm{bc}$ & $9 \pm 0.88 b$ \\
\hline SWE priming + foliar spray & $4.95 \pm 0.19 c$ & $4.20 \pm 0.05 \mathrm{~d}$ & $53 \pm 2.08 b$ & $136 \pm 2.40 \mathrm{c}$ & $0.95 \pm 0.02 \mathrm{a}$ & $9 \pm 1.54 b$ \\
\hline MLE priming + foliar spray & $4.32 \pm 0.20 \mathrm{~d}$ & $3.49 \pm 0.07$ ef & $68 \pm 0.88 \mathrm{a}$ & $167 \pm 6.89 \mathrm{a}$ & $1.08 \pm 0.04 \mathrm{a}$ & $11 \pm 0.58 \mathrm{a}$ \\
\hline LSD Interaction at $p>0.05$ & 0.45 & 0.70 & 8.15 & 11.11 & 0.13 & 1.97 \\
\hline
\end{tabular}

MET $=$ mean emergence time, $E_{50}=$ time taken to $50 \%$ emergence, MLE, moringa leaf extract; SWE, sorghum water extract; LSD, least significant difference test. Means within a column followed by the same letters are not significantly different at $p \leq 0.05$. 


\subsection{Growth Parameters}

Comparison of treatment means revealed that the majority of exogenously-applied growth-promoting substances significantly improved plant density over the control (Table 1). Maximum plant density ( 68 plants $/ \mathrm{m}^{2}$ ) was observed for priming plus foliar spray with MLE which was statistically similar to MLE priming alone, followed by hydropriming (Table 2). Plant density was lower in control treatment with 36 plants $/ \mathrm{m}^{2}$.

Plant height, an index of the biological yield of the crop, was positively influenced by priming and foliar treatments. Comparison of treatments showed that some treatments enhanced plant height of sorghum compared to the control. Maximum plant height $(167 \mathrm{~cm})$ was seen in priming plus foliar spray with MLE treatment followed by MLE priming and foliar spray alone, which were statistically similar (Table 2). Priming plus foliar spray with MLE gave the thickest stem diameter $(1.1 \mathrm{~cm})$ which was statistically equivalent with priming plus foliar spray with SWE $(0.95 \mathrm{~cm})$. Our study showed that the maximum number of leaves (11) was produced by priming plus foliar spray with MLE compared to control (7), which was almost statistically similar (Table 2).

Similarly, maximum average weight of leaves per plant $(62.2 \mathrm{~g})$ and leaf area per plant were achieved by priming plus foliar spray with MLE, followed by priming plus foliar spray with SWE and foliar spray with MLE (Table 3). Compared to control ( $235 \mathrm{~g} / \mathrm{plant})$, the highest value ( $311 \mathrm{~g} / \mathrm{plant})$ for fresh weight of sorghum was also seen due to priming plus foliar application of MLE followed by foliar spray with MLE and it was statistically similar to priming alone with MLE. None of the other exogenous application treatments had any significant differences with respect to each other (Table 3).

Similar results were observed for dry weight per plant which were increased to a maximum value of $78 \mathrm{~g} /$ plant by priming plus foliar spray of MLE compared to the control which had the lowest value (59 g/plant; Table 3).

\subsection{Biochemical Analysis}

Chlorophyll content of leaves is related to the photosynthetic activity of plants. Exogenously applied plant growth-promoting substances increased chlorophyll ' $a$ ' contents. Comparison of treatment means revealed that priming plus foliar spray with MLE increased chlorophyll ' $a$ ' contents to a maximum $(1.3 \mathrm{mg} / 100 \mathrm{~mL}$; Figure $3 \mathrm{a})$, that was statistically similar to treatments with MLE alone. These highest values were followed by all other treatments, which did not significantly differ from each other. None of the exogenously applied plant growth-promoting substances had any significant effect on chlorophyll ' $b$ ' contents (Figure 3b).

\subsection{Quality Attributes}

Quality parameters of sorghum were significantly influenced by exogenous application of natural plant growth-promoting substances (Table 1). Fodder with less crude fiber increases quality because of better intake, palatability and digestibility. The highest crude fiber percentage (30.8\%) was obtained by priming with SWE. This was statistically similar to hydropriming (30.7\%), foliar spray with SWE (30.8\%) and priming plus foliar spray with water (30.7\%) (Figure 4a). Priming plus foliar spray with MLE resulted in significantly less crude fiber (29\%) compared to all other treatments including control (30.5\%).

Crude protein is an important quality determinant of fodder. Priming plus foliar spray with MLE produced significantly higher crude protein content (9.2\%) compared to all other treatments, followed by foliar spray alone as well as priming alone treatments of MLE. Both these latter treatments increased protein contents by $8.7 \%$ and $8.6 \%$, respectively (Figure $4 \mathrm{~b}$ ). Data regarding ash percentage also showed that priming plus foliar spray with MLE gave the highest value $(10.1 \%)$ as compared to all other treatments (Figure 4c). The lowest amount of ash $(7.8 \%)$ was recorded in non-treated control seeds. 
Table 3. Effect of seed priming and foliar application strategies on agronomic traits and yield attributes of sorghum under field conditions.

\begin{tabular}{|c|c|c|c|c|c|c|}
\hline Treatments & $\begin{array}{l}\text { Leaf Weight Per } \\
\text { Plant (g) }\end{array}$ & $\begin{array}{c}\text { Leaf Area Per } \\
\text { Plant }\left(\mathrm{m}^{2}\right)\end{array}$ & $\begin{array}{c}\text { Fresh Weight Per } \\
\text { Plant (g) }\end{array}$ & $\begin{array}{l}\text { Dry Weight Per } \\
\text { Plant (g) }\end{array}$ & $\begin{array}{c}\text { Total Forage Yield } \\
\left(\mathrm{t} \cdot \mathrm{ha}^{-1}\right)\end{array}$ & $\begin{array}{l}\text { Total Dry Matter } \\
\text { Yield }\left(\mathrm{t} \cdot \mathrm{ha}^{-1}\right)\end{array}$ \\
\hline Control & $47.00 \pm 0.51 \mathrm{c}$ & $325 \pm 2.89 \mathrm{e}$ & $235 \pm 2.60 c$ & $59 \pm 0.65 c$ & $43 \pm 0.57 b$ & $11.68 \pm 0.14 c$ \\
\hline Hydropriming & $46.67 \pm 0.99 c$ & $326 \pm 3.28 \mathrm{de}$ & $234 \pm 4.67 c$ & $59 \pm 1.17 c$ & $42 \pm 2.12 b$ & $10.51 \pm 0.53 c$ \\
\hline SWE Priming & $46.67 \pm 1.10 c$ & $329 \pm 5.36$ cde & $234 \pm 5.55 c$ & $58 \pm 1.39 c$ & $44 \pm 1.96 \mathrm{~b}$ & $10.95 \pm 0.49 \mathrm{bc}$ \\
\hline MLE Priming & $56.23 \pm 2.40 \mathrm{~b}$ & $336 \pm 3.61$ cde & $280 \pm 2.31 b$ & $70 \pm 0.58 b$ & $48 \pm 1.20 \mathrm{a}$ & $12.81 \pm 0.30 \mathrm{a}$ \\
\hline Water foliar spray & $48.08 \pm 0.65 c$ & $328 \pm 3.53$ de & $241 \pm 3.06 \mathrm{c}$ & $60 \pm 0.78 c$ & $42 \pm 0.62 b$ & $10.62 \pm 0.16 c$ \\
\hline SWE foliar spray & $46.27 \pm 1.20 c$ & $336 \pm 3.18 \mathrm{~cd}$ & $232 \pm 6.12 c$ & $58 \pm 1.53 c$ & $42 \pm 1.59 \mathrm{~b}$ & $10.54 \pm 0.40 c$ \\
\hline MLE foliar spray & $57.34 \pm 1.80 \mathrm{~b}$ & $340 \pm 2.91 c$ & $286 \pm 12.91 \mathrm{~b}$ & $71 \pm 3.23 \mathrm{~b}$ & $49 \pm 1.89 \mathrm{a}$ & $12.82 \pm 0.47 \mathrm{a}$ \\
\hline Water priming + foliar spray & $46.13 \pm 0.92 c$ & $326 \pm 4.04 \mathrm{de}$ & $230 \pm 4.51 c$ & $57 \pm 1.00 \mathrm{c}$ & $42 \pm 1.57 \mathrm{~b}$ & $10.50 \pm 0.39 c$ \\
\hline SWE priming + foliar spray & $48.61 \pm 0.63 c$ & $361 \pm 3.22 b$ & $241 \pm 8.67 c$ & $60 \pm 2.17 c$ & $45 \pm 1.35 b$ & $11.82 \pm 0.34 b$ \\
\hline MLE priming + foliar spray & $62.24 \pm 1.14 \mathrm{a}$ & $381 \pm 4.58 \mathrm{a}$ & $311 \pm 4.93 \mathrm{a}$ & $78 \pm 1.23 \mathrm{a}$ & $52 \pm 0.49 a$ & $12.91 \pm 0.12 \mathrm{a}$ \\
\hline LSD Interaction at $p \geq 0.05$ & 3.50 & 11.20 & 17.64 & 4.40 & 3.39 & 0.90 \\
\hline
\end{tabular}

MLE, moringa leaf extract; SWE, sorghum water extract. Means within a column followed by the same letters are not significantly different at $p \leq 0.05$ 

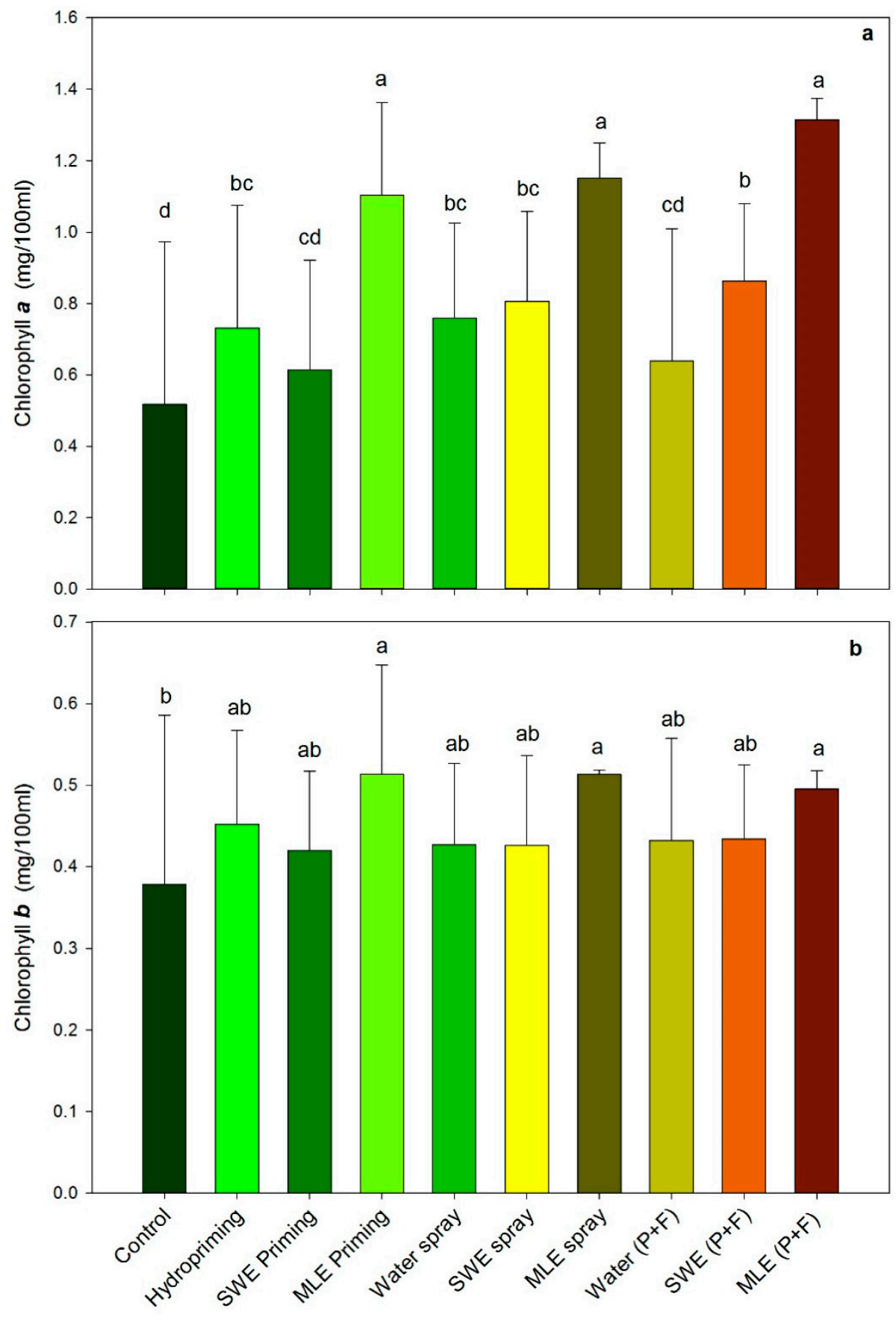

Priming and Foliar Treatments

Figure 3. Chlorophyll contents (a) chlorophyll $a$; (b) chlorophyll $b$ of sorghum as affected by seed priming and foliar application strategies under field conditions. The capped bars above means represent S.E. (standard error) of three replicates. Means with different lower case letters differ significantly at $p \leq 0.05$. MLE, moringa leaf extract; $S W E$, sorghum water extract; $P$, priming; $F$, foliar spray. 

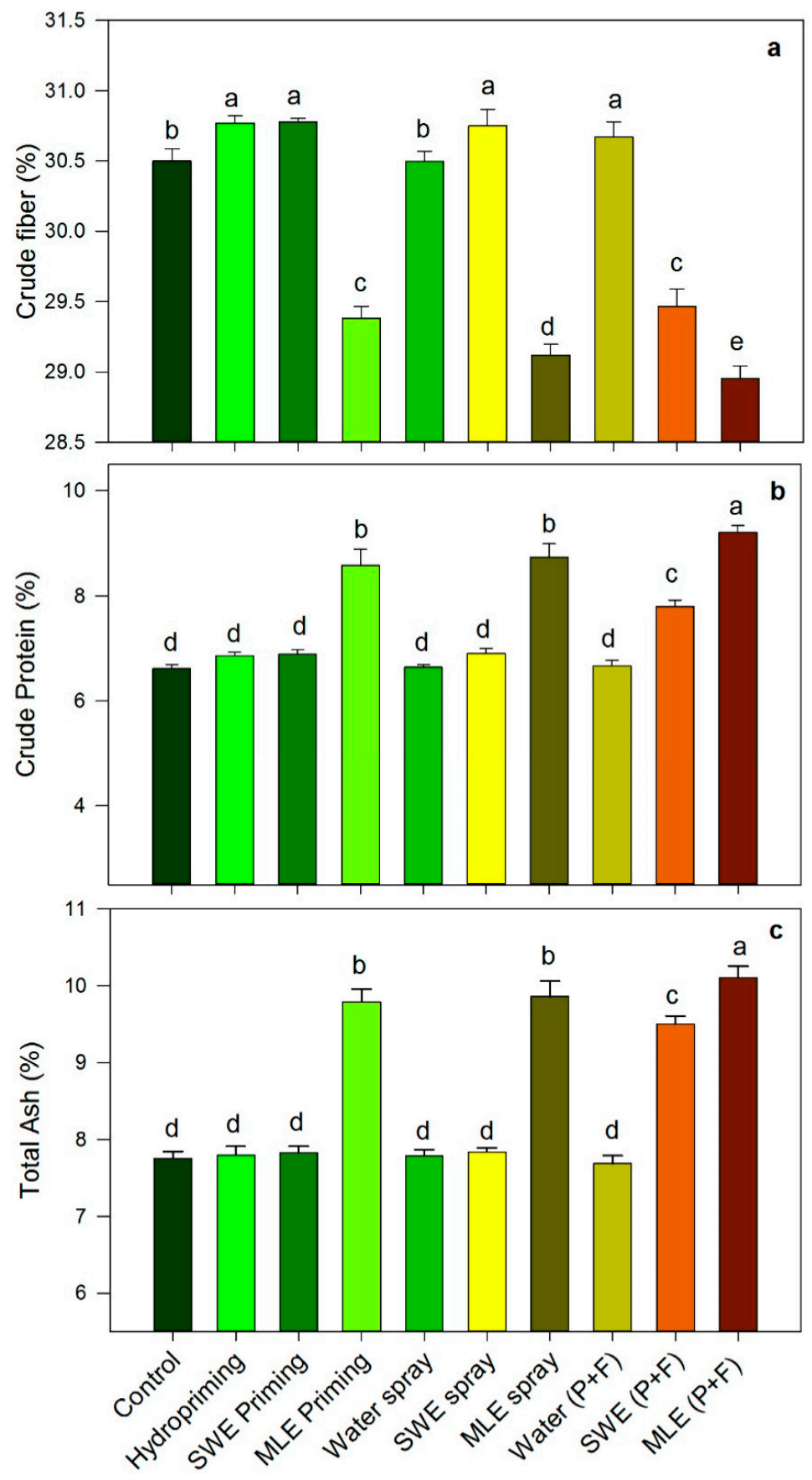

Priming and Foliar Treatments

Figure 4. Quality attributes ((a), fiber; (b) protein; (c) ash) of sorghum as affected by seed priming and foliar application treatments under field conditions. The capped bars above means represent S.E. of three replicates. Means with different lower case letters differ significantly at $p \leq 0.05$. MLE, moringa leaf extract; SWE, sorghum water extract; P, priming; F, foliar spray.

\subsection{Yield Parameters}

Maximum green forage yield ( $52 \mathrm{t} \cdot \mathrm{ha}^{-1}$ ) was obtained by priming plus foliar spray with MLE, followed by MLE foliar and priming alone treatments, as these produced the forage yields of 49 and $48 \mathrm{t} \cdot \mathrm{ha}^{-1}$ respectively, and were statistically similar (Table 3). Un-treated seeds produced the lowest green forage yield $\left(43 \mathrm{t} \cdot \mathrm{ha}^{-1}\right)$. 
Priming plus foliar spay with MLE also resulted in the highest dry matter yield (12.9 t.ha $\left.{ }^{-1}\right)$ but this was statistically similar to that of the foliar spray and priming with MLE alone. Non-treated sorghum seeds produced the lowest dry matter yield $\left(10.7 \mathrm{t} \cdot \mathrm{ha}^{-1}\right)$ (Table 3$)$.

\section{Discussion}

Seed priming improved germination by triggering some biochemical changes including starch hydrolysis, enzyme activation and breaking seed dormancy [34] as seeds germinate quickly after priming due to prompt availability of food reserves [19]. Presence of growth-promoting substances like zeatin and antioxidants in MLE [10], and phenolics and secondary metabolites in SWE improve the germination and confer stress tolerance to the emerging seeds. Exogenous application of natural growth-promoting substances is used to reduce germination time, harmonize germination, and improve emergence rate as well as seedling stand in many field crops $[15,19]$ and the present study further confirmed the efficacy of natural growth-promoting substances by vigorous emergence and seedling growth of sorghum. Seeds primed with MLE as well as SWE had higher vigor levels $[11,35]$ and resulted in an earlier start of germination as seen in the study by Hernandez et al. [36], showing that high vigor seed lots performed better than low vigor ones. Early emergence as indicated by lower $E_{50}$ and MET in treated seeds may be due to the faster production of germination metabolites [37-39] and better genetic repair [40]. Seeds treated exogenously with MLE and SWE improved in performance and daily emergence (Figure 2), with reduced MET and time to 50\% emergence (Table 2).

Priming followed by foliar spray with MLE was shown to best improve stem diameter, plant height, average leaf weight per plant, fresh and dry weight per plant (Tables 2 and 3). Increments in plant density, height, stem diameter, number of leaves, leaf weight, fresh and dry weight per plant may be the result of faster field emergence (Figure 2) and a vigorous start with good seedling stand establishment as depicted by MET and $E_{50}$ (Table 1). Similar findings were published by Yasmeen et al. [21], confirming significant improvement in growth and development due to MLE application by boosting seedling stand establishment.

Similar increases in stem diameter by priming and foliar spray of PGRs were found by Foidl et al., [10] and Makkar and Becker [41]. Leaf area increased in MLE priming plus foliar spray treatment because MLE had zeatin, phenolics, carotenoids, ascorbic acid, potassium and calcium [10]. It also bears plant growth-enhancing abilities by delaying leaf senescence and increasing the leaf area [42-44]. Among the plant growth regulators, zeatin, a naturally occurring form of cytokinins present in MLE, has a critical role in promotion of cell division and modification in apical dominance in plants, ultimately enhancing the growth of crop plants [45] and higher plant density. Foliar application of SWE reduced the oxidative damage to cell membranes due to ROS production under temperature stress [46], as plenty of phenolics are present in SWE [47]. The increase in leaf weight, plant fresh and dry weight is due to the presence of minerals and growth-regulating chemicals in MLE, which may act as organic fertilizers (foliar or seed priming) to improve yield by increasing all yield contributing parameters.

Improved physiological parameters (chlorophyll $a, b$ ) by priming and foliar treatments of MLE may be the result of enhanced tolerance with respect to high temperatures, resulting in elevated chlorophyll $a$ content as compared to control seeds (Figure 3). Ali et al. [44] reported increased leaf area, relative water contents and chlorophyll ' $a$ ' contents in forage crop with MLE application. Liu and Huang [48] similarly found that zeatin (found in MLE) applied to creeping bent grass improved the leaf chlorophyll content because of reduced degeneration of chlorophyll and production of new cells.

Abrupt fluctuations in daily minimum and maximum temperatures were observed during early (9 DAS) and late vegetative (36 DAS) stages, ranging from very low $\left(15^{\circ} \mathrm{C}\right)$ to ultra-high $\left(45^{\circ} \mathrm{C}\right)$ temperatures during the crop season (Figure 1). A significant role of applied PGRs (MLE and SWE) in alleviating temperature stress effects in the early stage $\left(15^{\circ} \mathrm{C}\right)$ of the sorghum crop as well as during late vegetative stage (up to $44.6^{\circ} \mathrm{C}$ ) was possibly attributed towards ROS scavenging activities performed by phenolics and antioxidants present in SWE and MLE [10,47], as overproduction of 
ROS under abiotic stress affects the plant antioxidant defense system [49]. Improved chlorophyll contents due to MLE application might be the result of maintenance in tissue water relations and improved carbohydrate metabolism [9], due to detoxifying moringa leaf elements. Therefore, increased chlorophyll content under high temperatures can be an indication of heat stress tolerance as reflected by the stabilization of important physiological processes (photosynthesis) which are sensitive to heat stress [50]. Tissue senescence due to oxidative membrane damage is a typical symptom of heat stress [51].

Significant improvement in crude fiber, crude protein and total ash (Figure 4) due to MLE priming and foliar spray is attributed to the presence of minerals like calcium, potassium and growth-enhancing elements such as zeatin and ascorbate in moringa leaves [10] which increased the protein and ash contents by decreasing crude fiber percentage. Our results further confirmed the findings of Cag et al. [52], Nouman et al. [53] Yasmeen et al. [21], and Bakhtavar et al. [11], who described improved crude protein percentage for MLE application as a result of enhanced enzyme activities. Moreover, improved forage nutritional quality might be the result of efficient translocation of photoassimilates and improved carbohydrate metabolism due to the beneficiary elements of MLE [54].

Total forage yield and total dry matter yield was increased by MLE priming and foliar application (Table 3), due to improved and faster emergence. In addition, primed seeds imbibed maximum amount of moisture and nutrients from MLE and SWE during priming and emerged earlier due to enhanced enzymatic and metabolic activities in seed endosperm. MLE application increased plant height due to production of new cells at shoot apical meristem, and due to this increased cell division, the leaf area of plants increased along with improved chlorophyll and photosynthetic activity, thus increasing total biomass [48]. Similarly, Fuglie [55] observed that the growth-enhancing substances in MLE may reduce the adverse effects of high temperature by scavenging reactive oxygen species and finally increasing yield.

\section{Conclusions}

The study concludes that exogenous application of growth-promoting substances improved the emergence, growth, biochemical, yield and quality attributes of sorghum through conferring tolerance against temperature extremes. The study also suggests the use of moringa leaf extract and sorghum water extract as an organic source of growth-promoting substances, antioxidants and secondary metabolites for crops under a changing climate.

Author Contributions: Irfan Afzal and Wahid Ahmad conceived and designed the experiment; Wahid Ahmad and Mehmood Ali Noor performed the experiment; Wahid Ahmad, Irfan Afzal, and Baoyuan Zhou analyzed the data; Xuefang Sun, Wei Ma and Ming Zhao contributed reagents/materials/analysis tools; Mehmood Ali Noor, Wahid Ahmad, Muhammad Mohsin Nawaz and Muhammad Amir Bakhtavar wrote the paper.

Conflicts of Interest: The authors declare no conflict of interest.

\section{References}

1. Barbeau, C.; Oelbermann, M.; Karagatzides, J.; Tsuji, L. Sustainable agriculture and climate change: Producing potatoes (Solanum tuberosum L.) and bush beans (Phaseolus vulgaris L.) for improved food security and resilience in a canadian subarctic first nations community. Sustainability 2015, 7, 5664-5681. [CrossRef]

2. Plaut, Z.; Butow, B.; Blumenthal, C.; Wrigley, C. Transport of dry matter into developing wheat kernels and its contribution to grain yield under post-anthesis water deficit and elevated temperature. Field Crops Res. 2004, 86, 185-198. [CrossRef]

3. Van Oijen, M.; Ewert, F. The effects of climatic variation in europe on the yield response of spring wheat cv. Minaret to elevated co 2 and o 3: An analysis of open-top chamber experiments by means of two crop growth simulation models. Eur. J. Agron. 1999, 10, 249-264. [CrossRef]

4. Schöffl, F.; Prandl, R.; Reindl, A. Molecular responses to heat stress. In Molecular Responses to Cold, Drought, Heat and Salt Stress in Higher Plants; R.G. Landes Company: Austin, TX, USA, 1999; pp. 81-98. 
5. Howarth, C. Genetic improvements of tolerance to high temperature. In Abiotic Stresses_Plant Resistance through Breeding and Molecular Approaches; Ashraf, M., Harris, P.J.C., Eds.; The Haworth Press: New York, NY, USA, 2005; pp. 277-300.

6. Feller, U.; Crafts-Brandner, S.J.; Salvucci, M.E. Moderately high temperatures inhibit ribulose-1,5-bisphosphate carboxylase/oxygenase (rubisco) activase-mediated activation of rubisco. Plant Physiol. 1998, 116, 539-546. [CrossRef] [PubMed]

7. Crafts-Brandner, S.J.; Salvucci, M.E. Rubisco activase constrains the photosynthetic potential of leaves at high temperature and $\mathrm{CO}_{2}$. Proc. Natl. Acad. Sci. USA 2000, 97, 13430-13435. [CrossRef] [PubMed]

8. Nash, D.; Miyao, M.; Murata, N. Heat inactivation of oxygen evolution in photosystem ii particles and its acceleration by chloride depletion and exogenous manganese. Biochim. Biophys. Acta (BBA) Bioenerg. 1985, 807, 127-133. [CrossRef]

9. Farooq, M.; Aziz, T.; Wahid, A.; Lee, D.-J.; Siddique, K.H.M. Chilling tolerance in maize: Agronomic and physiological approaches. Crop Pasture Sci. 2009, 60, 501-516. [CrossRef]

10. Foidl, N.; Makkar, H.; Becker, K. The potential of Moringa oleifera for agricultural and industrial uses. In What Development Potential for Moringa Products; The Miracle Tree: The Multiple Attributes of Moringa: Danbury, CT, USA, 2001; pp. 45-76.

11. Bakhtavar, M.A.; Afzal, I.; Basra, S.M.A.; Noor, M.A. Physiological strategies to improve the performance of spring maize (Zea mays L.) planted under early and optimum sowing conditions. PLoS ONE 2015, 10, e0124441. [CrossRef] [PubMed]

12. Kamran, M.; Cheema, Z.A.; Farooq, M. Influence of foliage applied allelopathic water extracts on the grain yield, quality and economic returns of hybrid maize. Int. J. Agric. Biol. 2016, 18, 577-583. [CrossRef]

13. Yasmeen, A.; Basra, S.; Farooq, M.; Ur Rehman, H.; Hussain, N. Exogenous application of moringa leaf extract modulates the antioxidant enzyme system to improve wheat performance under saline conditions. Plant Growth Regul. 2013, 69, 225-233. [CrossRef]

14. Ashraf, M.; Foolad, M. Pre-sowing seed treatment-A shotgun approach to improve germination, plant growth, and crop yield under saline and non-saline conditions. Adv. Agron. 2005, 88, 223-271.

15. Afzal, I.; Basra, S.; Shahid, M.; Saleem, M. Physiological enhancements of spring maize (Zea mays L.) under cool conditions. Seed Sci. Technol. 2008, 36, 497-503. [CrossRef]

16. Noor, M.A.; Ahmad, W.; Afzal, I.; Salamh, A.; Afzal, M.; Ahmad, A.; Ming, Z.; Wei, M. Pea seed invigoration by priming with magnetized water and moringa leaf extract. Philipp. Agric. Sci. 2016, 99, 171-175.

17. Farooq, M.; Bajwa, A.A.; Cheema, S.A.; Cheema, Z.A. Application of allelopathy in crop production. Int. J. Agric. Biol. 2013, 15, 1367-1378.

18. Cheema, Z.A.; Farooq, M.; Khaliq, A. Application of allelopathy in crop production: Success story from Pakistan. In Allelopathy; Springer: Berlin/Heidelberg, Germany, 2013; pp. 113-143.

19. Afzal, I.; Noor, M.; Bakhtavar, M.; Ahmad, A.; Haq, Z. Improvement of spring maize performance through physical and physiological seed enhancements. Seed Sci. Technol. 2015, 43, 238-249. [CrossRef]

20. Khalafalla, M.M.; Abdellatef, E.; Dafalla, H.M.; Nassrallah, A.A.; Aboul-Enein, K.M.; Lightfoot, D.A. Active principle from moringa oleifera lam leaves effective against two leukemias and a hepatocarcinoma. Afr. J. Biotechnol. 2010, 9, 8467-8471.

21. Yasmeen, A.; Basra, S.M.A.; Wahid, A.; Nouman, W.; Rehman, H.U. Exploring the potential of moringa oleifera leaf extract (mle) as a seed priming agent in improving wheat performance. Turk. J. Bot. 2013, 37, 512-520.

22. Noctor, G.; Foyer, C.H. Ascorbate and glutathione: Keeping active oxygen under control. Annu. Rev. Plant Biol. 1998, 49, 249-279. [CrossRef] [PubMed]

23. Sène, M.; Gallet, C.; Doré, T. Phenolic compounds in a sahelian sorghum (Sorghum bicolor) genotype (ce145-66) and associated soils. J. Chem. Ecol. 2001, 27, 81-92. [CrossRef] [PubMed]

24. Einhellig, F.A.; Souza, I.F. Phytotoxicity of sorgoleone found in grain sorghum root exudates. J. Chem. Ecol. 1992, 18, 1-11. [CrossRef] [PubMed]

25. Ben-Hammouda, M.; Kremer, R.J.; Minor, H.C.; Sarwar, M. A chemical basis for differential allelopathic potential of sorghum hybrids on wheat. J. Chem. Ecol. 1995, 21, 775-786. [CrossRef] [PubMed]

26. Cheema, Z.A.; Khaliq, A.; Hussain, R. Reducing herbicide rate in combination with allelopathic sorgaab for weed control in cotton. Int. J. Agric. Biol. 2003, 5, 4-6. 
27. Abouziena, H.; Shararafaida, A.; El-Desoki, E. Efficacy of cultivar selectivity and weed control treatments on wheat yield and associated weeds in sandy soils. World J. Agric. Sci. 2008, 4, 384-389.

28. Association of Official Seed Analysts. AOSA Rules for Testing Seeds; Association of Official Seed Analysts: Washington, DC, USA, 1990; Volume 12.

29. Ellis, R.; Roberts, E. The quantification of ageing and survival in orthodox seeds. Seed Sci. Technol. (Neth.) 1981, 9, 373-409.

30. Coolbear, P.; FRANCIS, A.; Grierson, D. The effect of low temperature pre-sowing treatment on the germination performance and membrane integrity of artificially aged tomato seeds. J. Exp. Bot. 1984, 35, 1609-1617. [CrossRef]

31. Noor, M.A.; Fiaz, S.; Nawaz, A.; Nawaz, M.M. The effects of cutting interval on agro-qualitative traits of different millet (Pennisetum americanum L.) cultivars. J. Saudi Soc. Agric. Sci. 2016. [CrossRef]

32. Association of Official Analytical Chemist. Official Methods of Analysis, 15th ed.; Virginia Inc.: Waynesboro, VA, USA, 1990.

33. Steel, R.G.; Dickey, J.H. Pinciples and Procedures of Statistics a Biometrical Approach, 3rd ed.; Mc Graw Hill, Inc. Book Co.: New York, NY, USA, 1997.

34. Farooq, M.; Basra, S.M.A.; Ahmad, N.; Hafeez, K. Thermal hardening: A new seed vigor enhancement tool in rice. J. Integr. Plant Biol. 2005, 47, 187-193. [CrossRef]

35. Ruan, S.; Xue, Q.; Tylkowska, K. Effects of priming on germination and health of rice (Oryza sativa L.) seeds. Seed Sci. Technol. 2002, 30, 451-458.

36. Hernández, I.; Alegre, L.; Van Breusegem, F.; Munné-Bosch, S. How relevant are flavonoids as antioxidants in plants? Trends Plant Sci. 2009, 14, 125-132. [CrossRef] [PubMed]

37. Saha, R.; Mandal, A.; Basu, R. Physiology of seed invigoration treatments in soybean (Glycine max L.). Seed Sci. Technol. 1990, 18, 269-276.

38. Lee, S.-S.; Kim, J.-H. Total sugars, $\alpha$-amylase activity, and germination after priming of normal and aged rice seeds. Korean J. Crop Sci. 2000, 45, 108-111.

39. Basra, S.M.A.; Farooq, M.; Tabassam, R.; Ahmad, N. Physiological and biochemical aspects of pre-sowing seed treatments in fine rice (Oryza sativa L.). Seed Sci. Technol. 2005, 33, 623-628. [CrossRef]

40. Bray, C. Biochemical Processes during the Osmopnming of Seeds. In Seed Development and Germination; Kigel, J., Galih, G., Eds.; Marcel Dekker: New York, NY, USA, 1995; pp. 767-789.

41. Makkar, H.; Becker, K. Nutritional value and antinutritional components of whole and ethanol extraction M. Oleifera leaves. J. Anim. Feed Sci. Technol. 1996, 63, 311-322. [CrossRef]

42. Miller, C. Cytokinin control of some oxidative processes. In Physiology and Biochemistry of Cytokinins in Plants; Academic Publishing: The Hauge, The Netherlands, 1992; pp. 289-293.

43. Galuszka, P.; Frebort, I.; Šebela, M.; Sauer, P.; Jacobsen, S.; Peč, P. Cytokinin oxidase or dehydrogenase? Eur. J. Biochem. 2001, 268, 450-461. [CrossRef] [PubMed]

44. Ali, Z.; Basra, S.M.A.; Munir, H.; Mahmood, A.; Yousaf, S. Mitigation of drought stress in maize by natural and synthetic growth promoters. J. Agric. Soc. Sci. (Pak.) 2011, 7, 56-62.

45. Taiz, L.; Zeiger, E. Plant Physiology, 4th ed.; Sinauer Associates: Sunderland, MA, USA, 2006.

46. Jaleel, C.A.; Gopi, R.; Gomathinayagam, M.; Panneerselvam, R. Traditional and non-traditional plant growth regulators alters phytochemical constituents in catharanthus roseus. Process Biochem. 2009, 44, $205-209$. [CrossRef]

47. Rice-Evans, C.; Miller, N.; Paganga, G. Antioxidant properties of phenolic compounds. Trends Plant Sci. 1997, 2, 152-159. [CrossRef]

48. Liu, X.H.; Huang, B.R. Cytokinin effects on creeping bentgrass response to heat stress: II. Leaf senescence and antioxidant metabolism. Crop Sci. 2002, 42, 466-472. [CrossRef]

49. Ashraf, U.; Kanu, A.S.; Mo, Z.; Hussain, S.; Anjum, S.A.; Khan, I.; Abbas, R.N.; Tang, X. Lead toxicity in rice: Effects, mechanisms, and mitigation strategies-A mini review. Environ. Sci. Pollut. Res. 2015, 22, 18318-18332. [CrossRef] [PubMed]

50. Bita, C.; Gerats, T. Plant tolerance to high temperature in a changing environment: Scientific fundamentals and production of heat stress-tolerant crops. Front. Plant Sci. 2013, 4, 273. [CrossRef] [PubMed]

51. Savchenko, G.; Klyuchareva, E.; Abramchik, L.; Serdyuchenko, E. Effect of periodic heat shock on the inner membrane system of etioplasts. Russ. J. Plant Physiol. 2002, 49, 349-359. [CrossRef] 
52. Cag, S.; Cevahir-Oz, G.; Sarsag, M.; Goren-Saglam, N. Effect of salicylic acid on pigment, protein content and peroxidase activity in excised sunflower cotyledons. Pak. J. Bot. 2009, 41, 2297-2303.

53. Nouman, W.; Siddiqui, M.T.; Basra, S.M.A. Moringa oleifera leaf extract: An innovative priming tool for rangeland grasses. Turk. J. Agric. For. 2012, 36, 65-75.

54. Makkar, H.; Francis, G.; Becker, K. Bioactivity of phytochemicals in some lesser-known plants and their effects and potential applications in livestock and aquaculture production systems. Animal 2007. [CrossRef] [PubMed]

55. Fuglie, L. New Uses of Moringa Studied in Nicaragua; ECHO Development Notes \#68; ECHO Community: Bayswater, WA, USA, 2000.

(C) 2016 by the authors; licensee MDPI, Basel, Switzerland. This article is an open access article distributed under the terms and conditions of the Creative Commons Attribution (CC-BY) license (http://creativecommons.org/licenses/by/4.0/). 